\title{
Thermal performance of wavy finned absorber solar air heater
}

\author{
Abhishek Priyam ${ }^{1 *}$, Prabha Chand ${ }^{2}$ \\ ${ }^{1}$ Department of Mechanical Engineering, MPSTME, NMIMS University, Mumbai 400056, Maharastra, India \\ ${ }^{2}$ Department of Mechanical Engineering, N.I.T Jamshedpur, Jharkhand 831014, India
}

Corresponding Author Email: priyamanik06@gmail.com

https://doi.org/10.18280/ijht.360431

Received: 25 November 2017

Accepted: 5 August 2018

\section{Keywords:}

wavy fin., thermal performance, fin spacing, mass velocity

\begin{abstract}
This paper presents an experimental investigation on the thermal performance enhancement of solar air heater having wavy fins attached below the absorber plate. Tests were conducted to cover a wide range of parameters such as mass, velocity, fin spacing and insolation under actual outdoor conditions. The effect of these parameters on the thermal performance has been examined and the results have been compared with plane solar air heater. The maximum enhancement in thermal efficiency for wavy finned absorber solar air heater for fin spacing of $2 \mathrm{~cm}$ has been found to be $28.71 \%$ as compared to fin spacing of $6 \mathrm{~cm}$ and $116.67 \%$ as compared to plane solar air heater. The maximum value of $\Delta \mathrm{T} / \mathrm{I}$ for wavy fin spacing $2 \mathrm{~cm}, 6$ $\mathrm{cm}$ and plane solar air heater has been achieved as $0.067,0.048$ and $0.029 \mathrm{~m}^{2}-{ }^{\circ} \mathrm{C} / \mathrm{W}$ respectively. Wavy finned absorber solar air heater has been found to be 67.44 to $121.43 \%$ thermally efficient as compared to plane solar air heater within the investigated range of system i.e. fin spacing of 2 to $6 \mathrm{~cm}$ and operating parameters i.e. mass velocity of $0.0065-0.033 \mathrm{~kg} / \mathrm{s}-$ $\mathrm{m}^{2}$. A substantial enhancement in thermal efficiency was achieved in comparison to plane solar air heater and this improvement is a strong function of system and operating parameters.
\end{abstract}

\section{INTRODUCTION}

Solar energy is considered as an optimistic and green source of energy and also used for many industrial and domestic applications. In solar energy exertions, solar air heaters provide the moderate air temperatures and used for the drying of crops, space heating etc.[1]. The performance of plane solar air heater is found to be low due to the lower heat transfer coefficient between the absorber plate and the air flowing through the duct and thus leads to higher thermal losses to the ambient [2]. In order to improve the heat transfer rate in the solar air heater, fins, fins with baffles [3-5] artificial roughness [6-7] and packed beds [8-10] are introduced in the flow channel. Fins are the surfaces that extend from the absorber plate to enhance the heat transfer area, thus increases the heat transfer rate. Numerous research on heat transfer characteristics of fins such as plain, wavy, offset fins and louvered fins over the flat wall has been studied and a considerable augmentation in heat transfer takes place. Li et al. [11] studied the comparative performance for wavy fin and a plain fin with radiantly arranged winglets around each tube in fin and tube heat exchangers. Their results indicate that the heat transfer rate and pressure drop penalty of heat exchanger surfaces using wavy fin with five row tubes were almost same with six raw tubes wavy fin heat exchanger surfaces. Also, they developed the correlations for Nusselt number and friction factor. Optimised study of cross-cut flow control has been done by Gun et al. [12] for heat transfer enhancement in wavy fin heat exchangers by using concept of cross cut reference length (CRL). They found an optimal heat transfer when the cross-cut length was 0.4 CRL and in some cased optimum cross cut length was changed to $0.5 \mathrm{CRL}$ by considering pressure drop. The flow and heat transfer characteristics for humped wavy fins with different humped radii and Reynolds number were studied numerically and experimentally by Zhang et al. [13] The JF factors of different humped fins were higher than that of triangular fins. Their results showed that the overall thermohydraulic characteristics for humped fin patterns with different humped radii were better than that of triangular fin. A single-blow transient test technique was employed by Ranganayakulu et al. [14] to measure the Colburn J-factor versus Reynolds number characteristics of high efficiency compact heat exchanger surfaces having offset and wavy fins. They used experimental data to estimate NTU values for 5-types of fins and then compared with the theoretical steady state CFD model. So, the wavy fin is a promising element to provide superior performance with considerable pressure drop in heat exchangers. Hence, researchers have focused their attention to employ these fins in the air heater, which enhances the overall heat conductance. Kumar and Chand [15] developed a mathematical model for herringbone corrugated fins to predict the effect of system, operating and meteorological parameters on the thermal and thermohydraulic performance of solar air heater. They found an improvement of $20.4 \%$ in thermal efficiency with the penalty of increased pressure drop at fin spacing $2.5 \mathrm{~cm}$ and mass flow rate of $0.026 \mathrm{~kg} / \mathrm{s}$. Priyam and Chand [16] studied the effect of mass flow rate and fin spacing on thermal and thermohydraulic performances of wavy finned absorber solar air heater. Their mathematical model predicted an enhancement of $62.53-63.41 \%$ in thermal efficiency and $29.39-29.43 \%$ in the effective temperature rise for the investigated mass flow range of $0.0138-0.0834 \mathrm{~kg} / \mathrm{s}$. In an another study, the effect of the collector aspect ratio has been investigated on the thermal performances of wavy fin absorber solar air heater by Priyam and Chand [17]. They found that the 
performance of wavy fin solar air heater improved with the increase in the collector aspect ratio. Analytical study on the wavy fin solar air heater was done by Priyam and Chand [18] to study the effect of wavelength and amplitude of wavy fin on thermal and thermohydraulic performance. They found a grat enhancement in the thermal and thermohydraulic performance with the wavy fin solar air heater and an optimal thermal efficiency as $73.2 \%$ has been found for the wavelength $=7 \mathrm{~cm}$ and mass flow rate of $0.061 \mathrm{~kg} / \mathrm{s}$.

It is evident from the literature that by providing wavy fins along the fluid flow increases the amount of heat transfer in the solar air heater but no experimental investigation has been done on the wavy fin solar air heater. In the present work, an experimental investigation has been carried out on the thermal performance of solar air heater with sinusoidal wavy fins below the absorber. The effects of mass velocity and the fin spacing on the thermal performance and rise in air temperature has been studied. Also, the variation of thermal efficiency as a function of $\Delta T / I$ for various fin spacing were examined. The obtained results are compared with results available in the literature.

\section{MATERIALS AND METHODOLOGY}

\subsection{Experimental set up}

The experimental set-up consists of a blower, wooden rectangular channel, G.I pipe, orifice meter, flow control valve, digital manometer, J-type thermocouples as shown in fig.1.The various system and operating parameters used in the analysis are listed in Table 1 . The inner dimensions of the both rectangular channels were $1700 \mathrm{~mm}$ x $400 \mathrm{~mm}$ x $50 \mathrm{~mm}$. The test section has a length of $1200 \mathrm{~mm}$ and the flow straightener of $500 \mathrm{~mm}$ as per ASHRAE standards [19]. The side and the middle wall of the channel were of soft wood having thickness $25 \mathrm{~mm}$ and $40 \mathrm{~mm}$. The bottom of the channels has a 22 gauge G.I sheet over a $50 \mathrm{~mm}$ of glass wool insulation supported by $10 \mathrm{~mm}$ plywood at the bottom. G.I sheet acts as an absorber in plane solar air heater, whereas, the wavy fins were attached below the absorber in the wavy finned absorber solar air heater. A total of five absorbers A1, A2, A3, A4 and A5 have been made with the fin spacing 2, 3, 4, 5 and $6 \mathrm{~cm}$ respectively. The spacing between the glass cover and the absorber plate is 50 $\mathrm{mm}$. The fins as well as plate were blackened with blackboard paint. The area exposed is $0.48 \mathrm{~m}^{2}$ for both the collectors. A total of 24 thermocouples was used, out of which 5 were used to measure the plate temperature of each collector and 7 each to measure air temperature inside the duct. The positions of thermocouples over the test section to measure air and plate temperature has been shown in fig.2. All thermocouples were connected to a data logger for digital display. A total of three data loggers $(\mathrm{A}, \mathrm{B}, \mathrm{C})$ having 8-channels each has been used to record the temperature. The air mass flow rate flowing through duct was measured by using a calibrated orifice meter fitted with digital manometer. The calibration of orifice meter was done by fitting the orifice meter in series with the calibrated orifice plate with known coefficient of discharge. The outlet of the air heaters were connected to wooden convergent section coupled with G.I pipes, orifice meter, flow control valve and a $3 \mathrm{hp}, 3$-ph blower. The pictorial view of the experimental set-up is shown in fig.3. Insolation was recorded by a pyranometer as shown in fig. 4 with digital output.

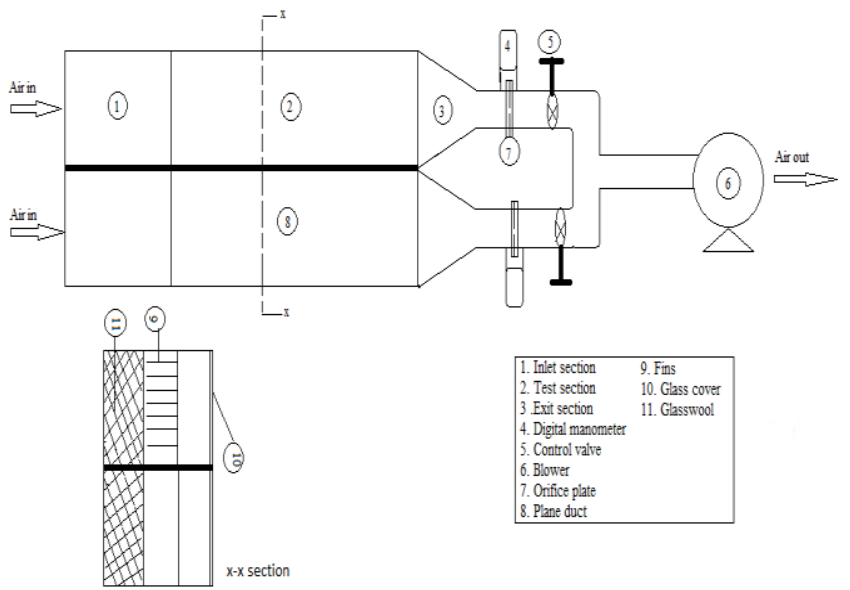

Figure 1. Schematic Diagram of Experimental set up

Table 1. System and operating parameters used

\begin{tabular}{|c|c|c|c|}
\hline Parameters & Value & Parameters & Value \\
\hline $\begin{array}{l}\text { Length of } \\
\text { Collector (L) }\end{array}$ & $\begin{array}{c}1200 \\
\mathrm{~mm}\end{array}$ & $\begin{array}{l}\text { Mass velocity } \\
\left(\dot{m} / A_{c}\right)\end{array}$ & $\begin{array}{c}0.0065, \\
0.0146, \\
0.02,0.025, \\
0.029,0.033 \\
\mathrm{~kg} / \mathrm{s}-\mathrm{m}^{2} \\
\end{array}$ \\
\hline $\begin{array}{c}\text { Width of } \\
\text { Collector }(\mathrm{W})\end{array}$ & $400 \mathrm{~mm}$ & Fin spacing (w) & $2,3,4,5,6 \mathrm{~cm}$ \\
\hline Duct height $(\mathrm{H})$ & $50 \mathrm{~mm}$ & $\begin{array}{c}\text { Thermal } \\
\text { conductivity of } \\
\left.\text { glass wool ( } \mathrm{kgw}_{\mathrm{gw}}\right)\end{array}$ & $\begin{array}{c}0.04 \mathrm{~W} / \mathrm{m}- \\
\mathrm{K}\end{array}$ \\
\hline $\begin{array}{c}\text { Thickness of fin } \\
\left(\delta_{\mathrm{f}}\right)\end{array}$ & $1 \mathrm{~mm}$ & $\begin{array}{c}\text { Thickness of } \\
\text { insulation }\left(\delta_{\text {ins }}\right)\end{array}$ & $50 \mathrm{~mm}$ \\
\hline $\begin{array}{l}\text { Actual length of } \\
\left.\text { fin ( } \mathrm{L}_{\text {act }}\right)\end{array}$ & $\begin{array}{c}1390 \\
\mathrm{~mm}\end{array}$ & $\begin{array}{c}\text { Amplitude of } \\
\text { wavy fin (amp) }\end{array}$ & $7.5 \mathrm{~mm}$ \\
\hline $\begin{array}{l}\text { Number of glass } \\
\text { covers }\left(\mathrm{N}_{\mathrm{gc}}\right)\end{array}$ & 1 & $\begin{array}{l}\text { Wavelength of } \\
\text { wavy fin }(\lambda)\end{array}$ & $70 \mathrm{~mm}$ \\
\hline Height of fin $\left(\mathrm{L}_{\mathrm{f}}\right)$ & $45 \mathrm{~mm}$ & & \\
\hline
\end{tabular}
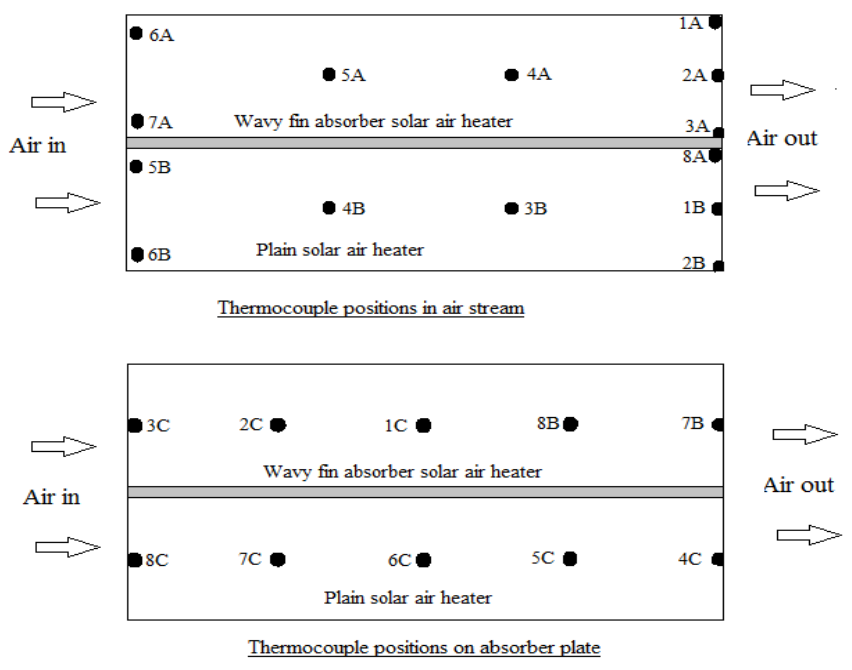

Figure 2. Positions of thermocouples in air stream and on absorber plate 


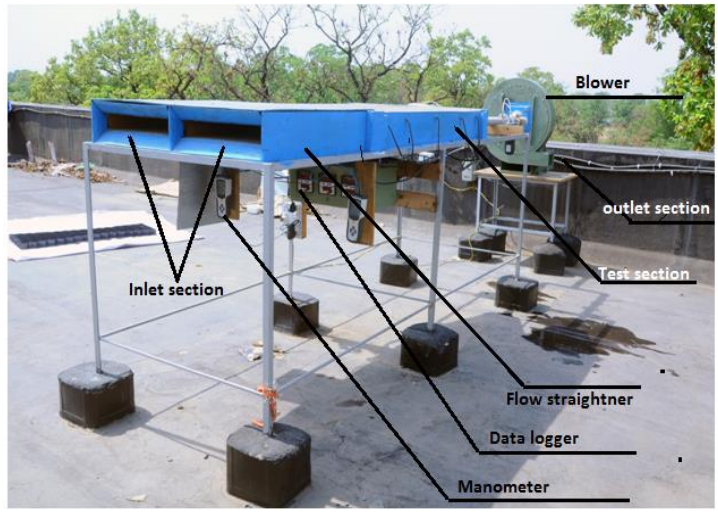

Figure 3. Photographic view of experimental set up
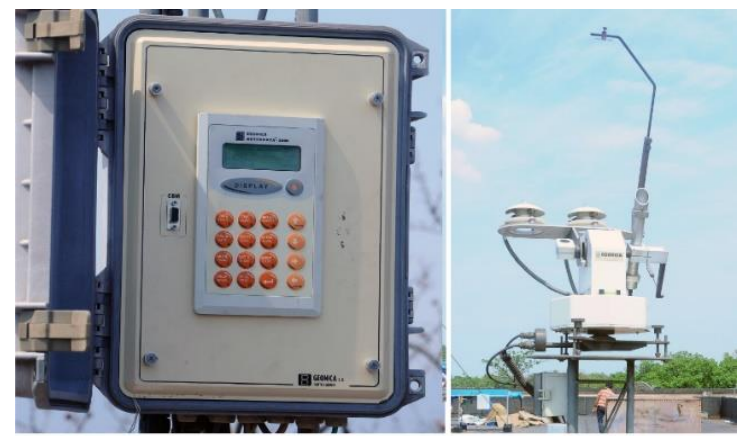

Figure 4. Pyramometer with digital output

\subsection{Experimentation}

The wavy fins of known physical characteristics were welded on the absorber plate as shown in fig.5 and fitted between the absorber plate and the bottom plate of solar air heater. The collectors were tested in the horizontal position as per ASHRAE-93 standards [19]. Outdoor testing of both plane and wavy fin solar air heater were done on clear sky days. Before the initiation of experimentation, all the components of the set up and the measuring instruments such as data logger, manometer and the pyranometer had been checked for their proper operation. After that the blower was switched on ensuring no leakage in the joints of duct. The mass flow rate in the duct was adjusted using a flow control valve. The blower was adjusted to run $1 \mathrm{hr}$ prior to the time at which the first data logging start. The temperature of the various thermocouples, wind speed, manometer reading and insolation were recorded daily at an interval of 30 minutes from 9:30 am to 4:30 pm. The test was run for a fixed mass velocity for a specific day. It was decided to take six values of mass flow rates (the partial opening to the full opening of the flow control valve) in order to cover the usual range of mass velocity and five sets of fin spacing.

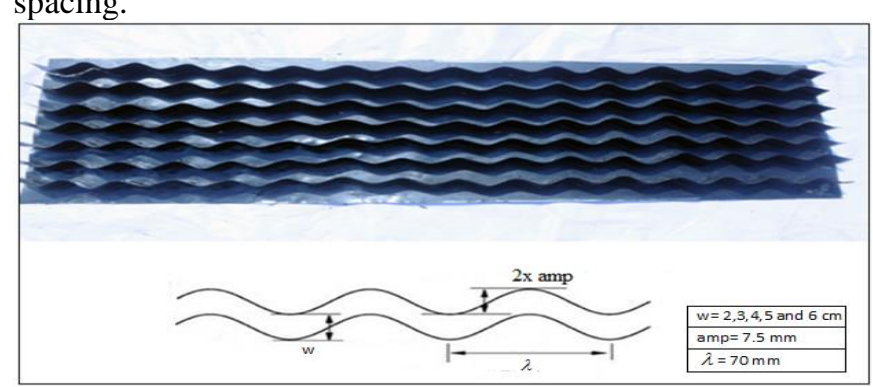

Figure 5. A typical absorber plate and its specification

\subsection{Thermal performance}

The data such as pressure drop across orifice plate, air and absorber plate temperature at various positions in the channel were recorded to compute the thermal performance of wavy finned absorber solar air heater. The following equations were used to calculate the air mass flow rate $(\dot{m})$, energy gain by air $\left(Q_{u}\right)$, thermal efficiency $(\eta)$ and heat conductance $(\bar{h} A)$,

$\dot{m}=C_{d} A_{0}\left[\frac{2 \rho \Delta P}{1-\beta^{4}}\right]^{0.5}$

where, $\Delta \mathrm{P}$ is the pressure drop across orifice.

The calibration result gives a value of 0.605 for $C_{d}$.

The energy gain by air is,

$Q_{u}=\dot{m} C_{p}\left(T_{0}-T_{i}\right)$

The average value of inlet air temperature $\left(\mathrm{T}_{\mathrm{i}}\right)$, outlet air temperature $\left(\mathrm{T}_{\mathrm{o}}\right)$, for wavy finned absorber solar air heater is calculated as,

$T_{i}=\frac{T_{6 A}+T_{7 A}}{2}$

$T_{o}=\frac{T_{1 A}+T_{2 A}+T_{3 A}}{3}$

and for plane solar air heater it is calculated as,

$T_{i}=\frac{T_{5 B}+T_{6 B}}{2}$

$T_{o}=\frac{T_{8 A}+T_{1 B}+T_{2 B}}{3}$

The thermal performance of flat plate solar air heater operating under quasi steady state conditions can be given by using the following equation [2];

$\eta=\frac{\dot{m} C_{p}\left(T_{o}-T_{i}\right)}{I A_{C}}$

Also, for the solar air heaters taking air at ambient temperature, the following equations for thermal efficiency can be given as [2]

$\eta=F_{0}\left[(\tau \alpha)_{e}-U_{L}\left(\frac{T_{0}-T_{i}}{I}\right)\right]$

where, $\mathrm{F}_{0}$ is the heat removal factor corresponding to outlet air temperature.

Equation shows the plot of efficiency as a function of $\left(T_{0}-T_{i}\right) / I$ will result a straight line with slope $-F_{0} U_{L}$ and the intercept $F_{0}(\tau \alpha)_{e}$. The solar air heaters test data 
presented as plots of thermal efficiency vs $\Delta \mathrm{T} / \mathrm{I}$, the intercept $F_{o}(\tau \alpha)$ and slope $-F_{o} U_{L}$ of these curves can be converted to $F_{R} U_{L}, F_{R}(\tau \alpha)_{e}$ and $F^{\prime} U_{L}$ by the following and suggested by Duffie \& Beckman [2].

$$
\begin{aligned}
& \mathrm{F}_{\mathrm{R}}(\tau \alpha)_{e}=\mathrm{F}_{0}(\tau \alpha)_{e}\left(1+\frac{A_{c} F_{0} U_{L}}{\dot{m} C_{P}}\right)^{-1} \\
& \mathrm{~F}_{\mathrm{R}} U_{L}=\mathrm{F}_{0} U_{L}\left(1+\frac{A_{c} F_{0} U_{L}}{\dot{m} C_{P}}\right)^{-1} \\
& \mathrm{~F}^{\prime} U_{L}=-\frac{\dot{m} C_{P}}{A_{c}} \ln \left(1-\frac{F_{R} U_{L} A_{c}}{\dot{m} C_{P}}\right)
\end{aligned}
$$

The equations (7) and (8) can be represented on a single plot having the same quantity, efficiency on ordinate and $\left(T_{0}-T_{i}\right) / I$ on abscissa. Also, this can be obtained from a single regression linear fit line from equation (8).

\subsection{Error analysis}

Although extreme care has been taken to perform experiments but there is always a chance of error in experimental measurements. So, it is necessary to determine the maximum possible error in the experimental measurements. The error analysis was done for the error interval associated with experimental results. The methodology suggested by Kline and Mc-Clintock [20] has been used to measure the error.

If the value of any parameter is calculated using certain measured quantities then error in measurement of ' $\varphi$ ' (parameters) is given as:

$$
\frac{\delta \varphi}{\varphi}=\left[\left(\frac{\delta \varphi}{\partial x_{1}} \delta x_{1}\right)^{2}+\left(\frac{\delta \varphi}{\partial x_{2}} \delta x_{2}\right)^{2}+\ldots \ldots \ldots \ldots . .+\left(\frac{\delta \varphi}{\partial x_{n}} \delta x^{n}\right)^{2}\right]^{0.5}
$$

where, $\delta x_{1}, \delta x_{2}, \delta x_{3} \ldots . . \delta x_{n}$ are the possible errors in measurements $x_{1}, x_{2}, x_{3} \ldots x_{n}$ and $\delta \varphi$ is called as absolute uncertainty and $\delta \varphi / \varphi$ is known as relative uncertainty. The fractional error analysis of the mass flow rate and the efficiency are found to be 0.0743 and 0.013 respectively. Table 6 shows the accuracy of measuring instruments.

\section{RESULTS AND DISCUSSION}

This experimental work investigates the effect of fin spacing of wavy finned absorber solar air heater under Jamshedpur, India weather between 14-04-2016 to 31-052016 with clear sky conditions. Jamshedpur city of India lies on the geographical coordinates of $22^{\circ} 48^{\prime} \mathrm{N}, 86^{\circ} 11^{\prime} \mathrm{E}$.

Fig. 6 shows the variation of insolation versus local time of all the days at which the study was conducted. As expected, the insolation increased from sunrise to peak at noon and then decreased in the afternoon till sunset. The average values of insolation for the experiments of 2, 3, 4, 5 and $6 \mathrm{~cm}$ spacing were $861.89,872.29,869.02,867.2$ and $858.3 \mathrm{~W} / \mathrm{m}^{2}$ respectively. The measured insolation were stable throughout the study.

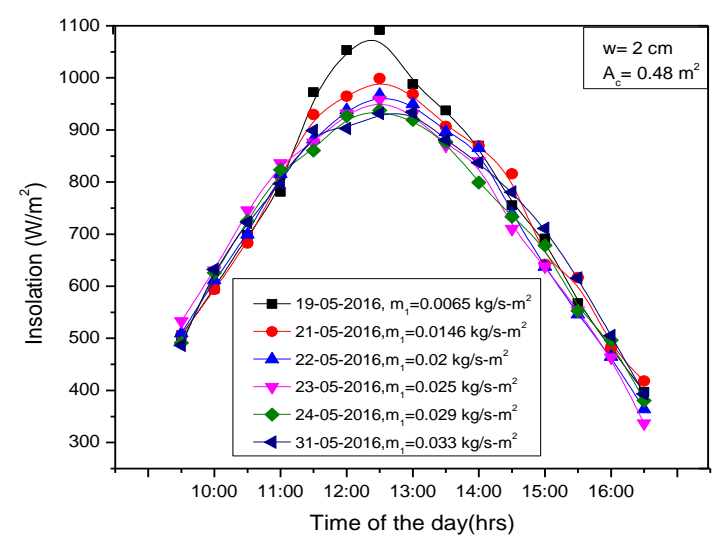

(a)

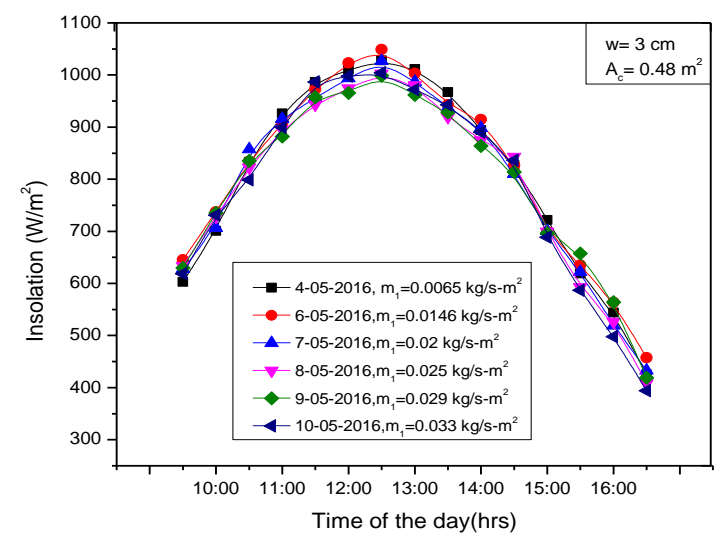

(b)

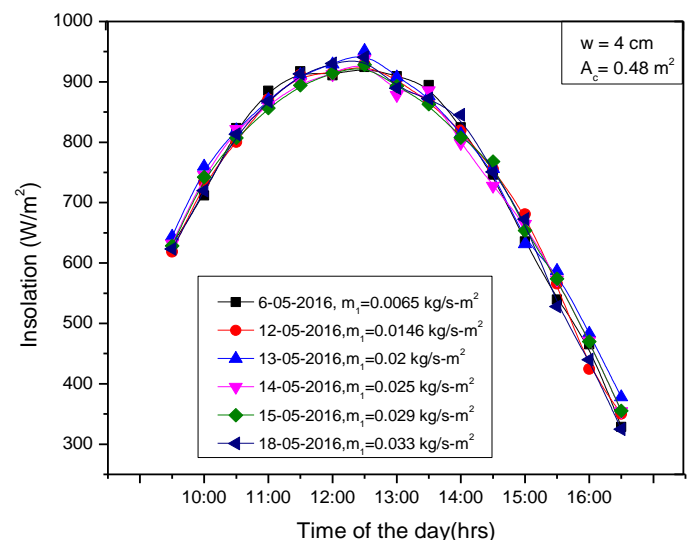

(c)

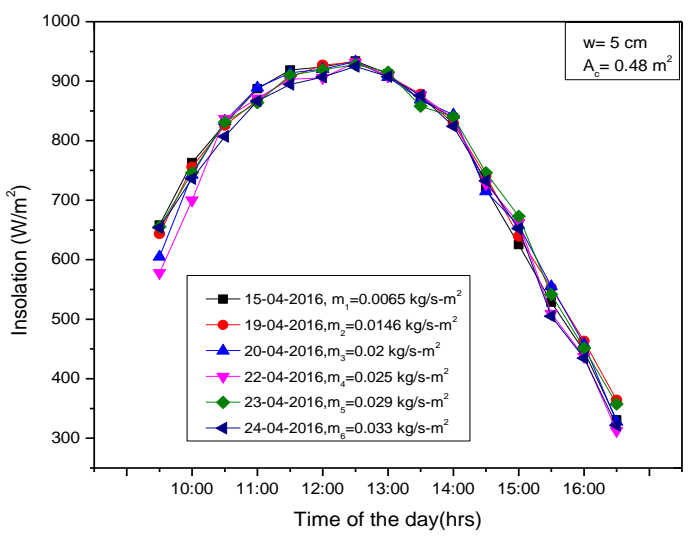

(d) 


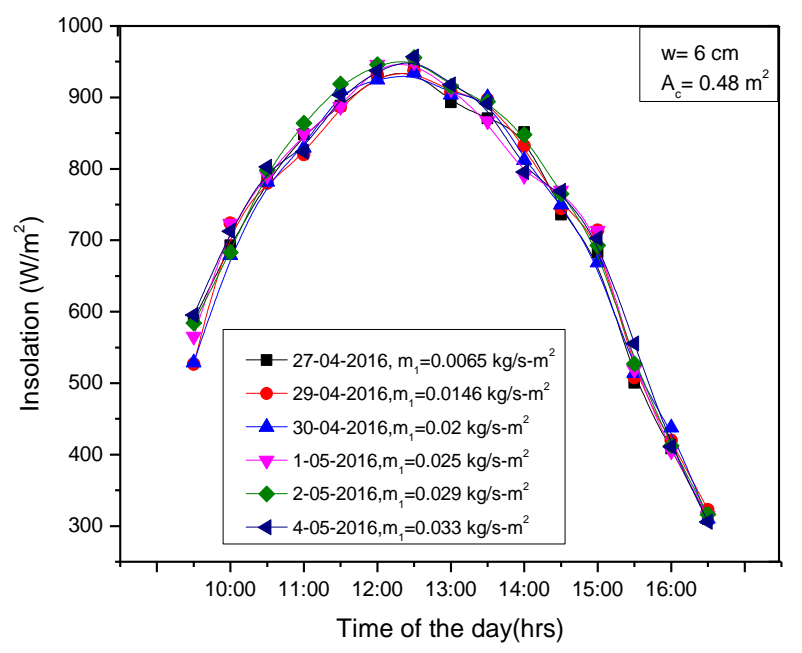

(e)

Figure 6. Variation of Insolation versus different standard local time of (a) $2 \mathrm{~cm}$ fin spacing (b) $3 \mathrm{~cm}$ fin spacing (c) 4 $\mathrm{cm}$ fin spacing (d) $5 \mathrm{~cm}$ fin spacing (e) $6 \mathrm{~cm}$ fin spacing

Fig.7 shows the air temperature rise at different mass velocities for 2, 3, 4, 5 and $6 \mathrm{~cm}$ fin spacing. As expected, for each cases, the value of the air temperature rise increases at sun rise to a maximum value at noon and start decreasing in the afternoon. Also, rise in temperature decreases with increasing mass velocity. The maximum value of the air temperature rise was achieved between 12:00 hr to 13:00 $\mathrm{hr}$ of local time and varied in magnitude for each day depending on the meteorological conditions such as wind speed and insolation. It also finds that the rise in air temperature increased by decreasing the fin spacing for the same mass velocity. As the fin spacing decreased, the velocity of air also increased for the same mass velocity. The highest average and instantaneous peak rise in air temperature obtained for lowest fin spacing $(2 \mathrm{~cm})$ were $50.47^{\circ} \mathrm{C}$ and $64.33^{\circ} \mathrm{C}$ respectively, with a mass velocity of $0.0065 \mathrm{~kg} / \mathrm{s}-\mathrm{m}^{2}$, whereas, the average and the maximum value of the air temperature rise obtained for maximum mass velocity of $0.33 \mathrm{~kg} / \mathrm{s}-\mathrm{m}^{2}$ were $33.51{ }^{\circ} \mathrm{C}$ and $46.13^{\circ} \mathrm{C}$, respectively. On the other hand, higher value of fin spacing $(6 \mathrm{~cm})$, the average and instantaneous peak rise in air temperature were obtained as $35.44^{\circ} \mathrm{C}$ and $48.13^{\circ} \mathrm{C}$ for lower mass velocity $\left(0.0065 \mathrm{~kg} / \mathrm{s}-\mathrm{m}^{2}\right)$ and $25.80^{\circ} \mathrm{C}$ and $37.68^{\circ} \mathrm{C}$ for higher mass velocity $\left(0.033 \mathrm{~kg} / \mathrm{s}-\mathrm{m}^{2}\right)$ respectively.

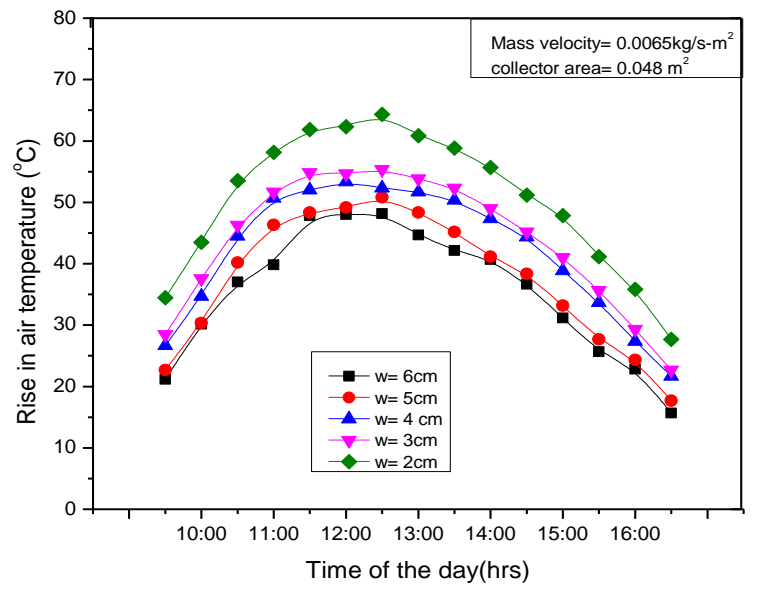

(a)

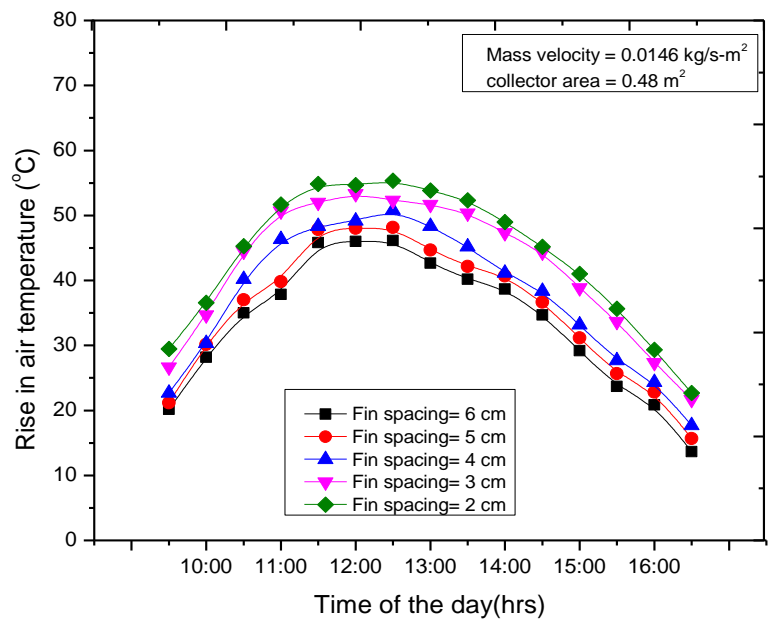

(b)

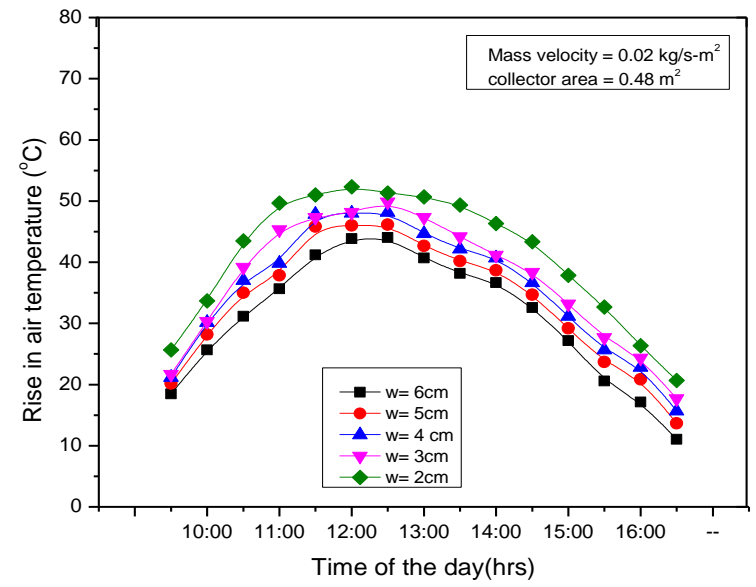

(c)

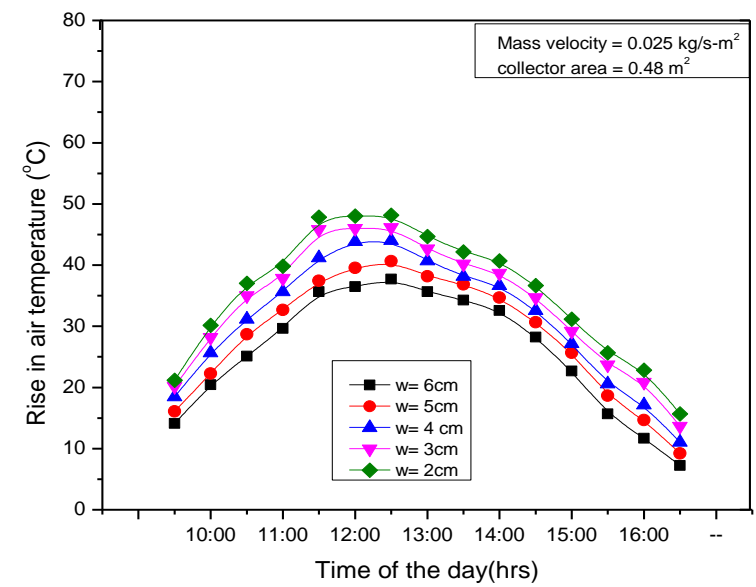

(d)

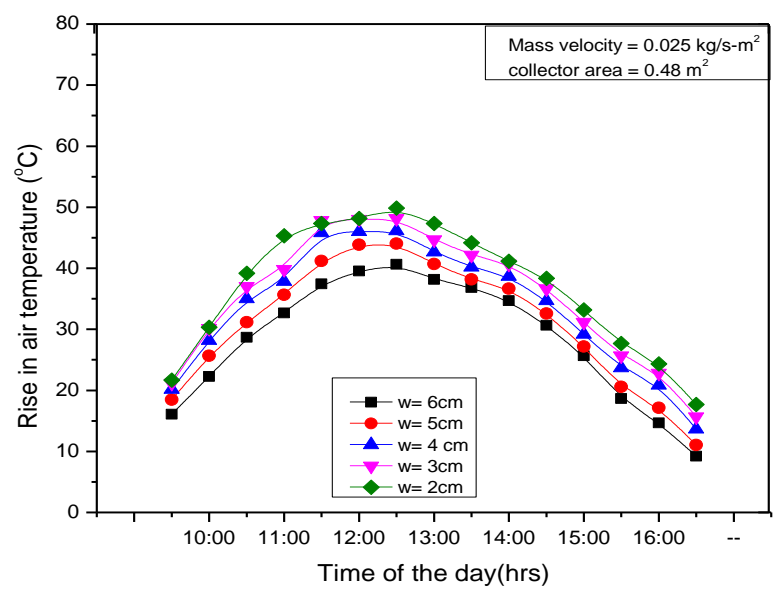

(e) 


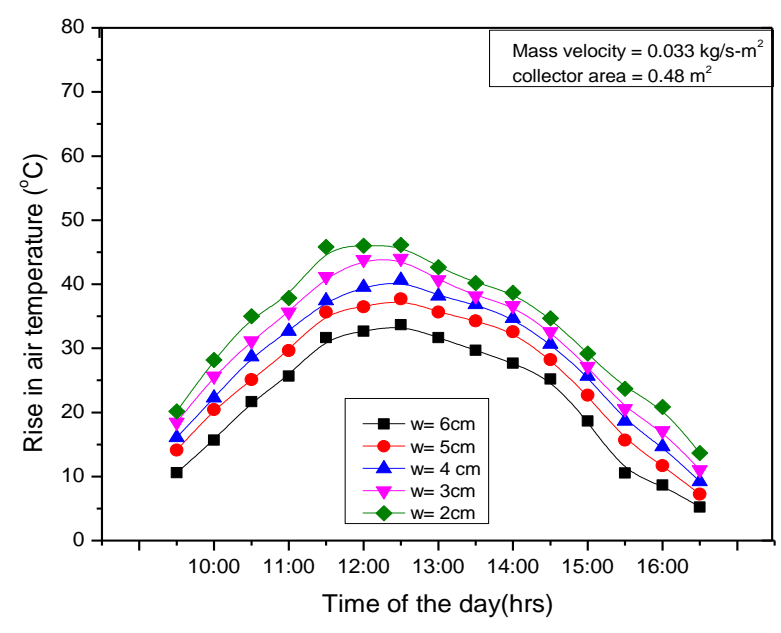

(f)

Figure 7. Effect of fin spacings on the temperature difference at mass velocities $\left(\mathrm{kg} / \mathrm{s}-\mathrm{m}^{2}\right)=$ (a) 0.0065 , (b) 0.0146 , (c) 0.02 , (d) 0.025 , (e) 0.029 , (f) 0.033

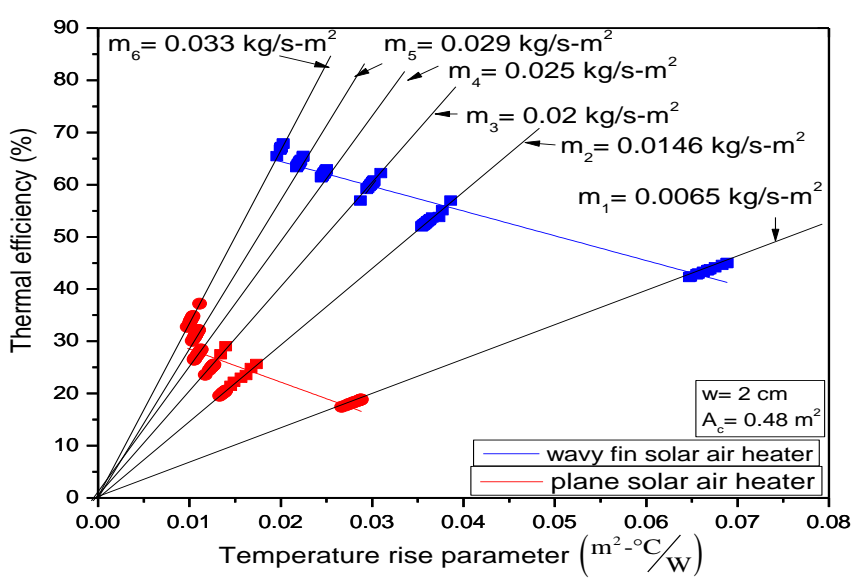

Figure 8. Performance plot for solar air heaters for fin spacing $2 \mathrm{~cm}$

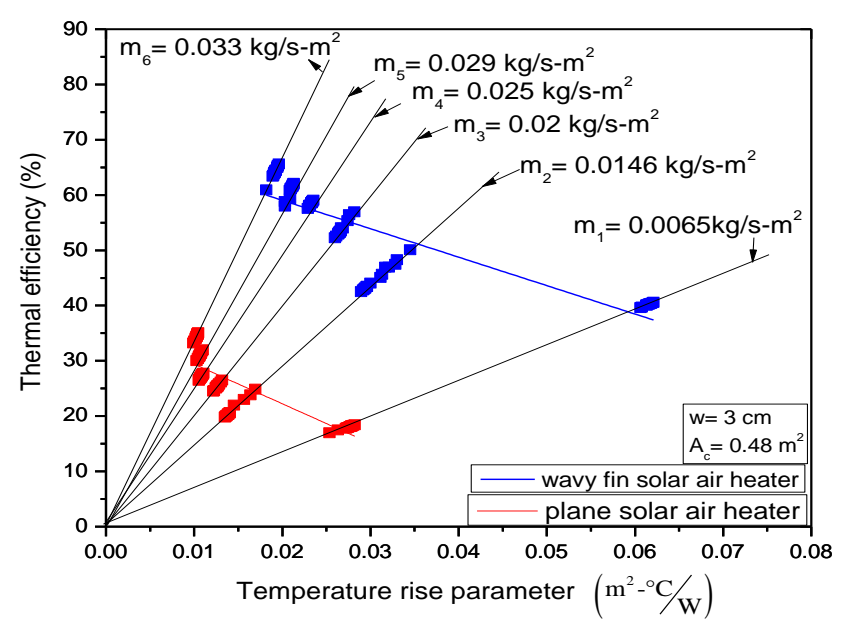

Figure 9. Performance plot for solar air heaters for fin spacing $3 \mathrm{~cm}$

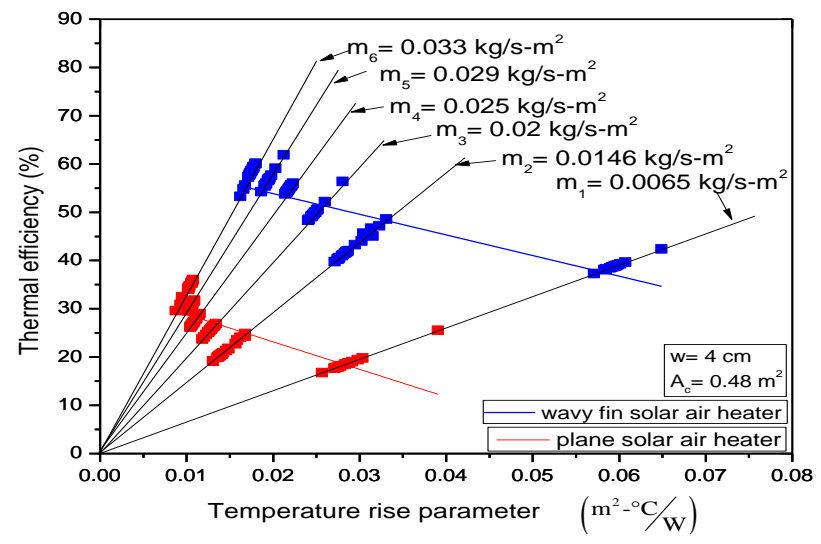

Figure 10. Performance plot for solar air heaters for fin spacing $4 \mathrm{~cm}$

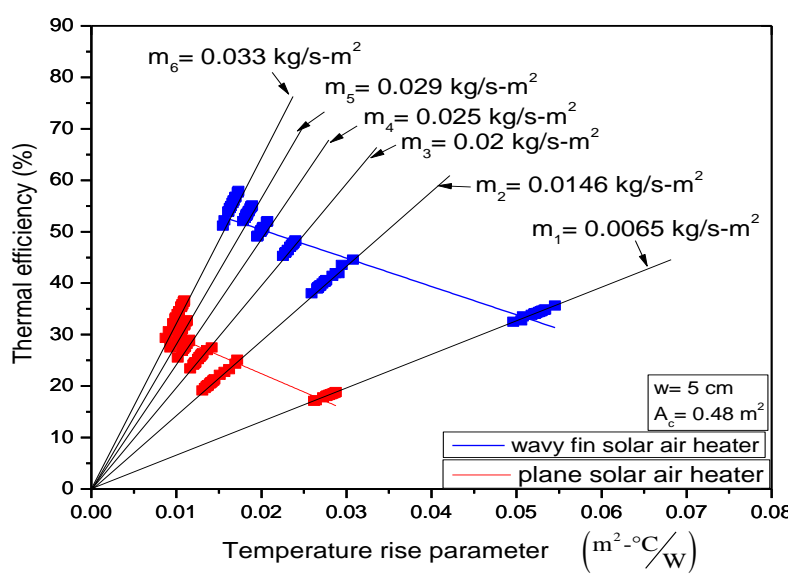

Figure 11. Performance plot for solar air heaters for fin spacing $5 \mathrm{~cm}$

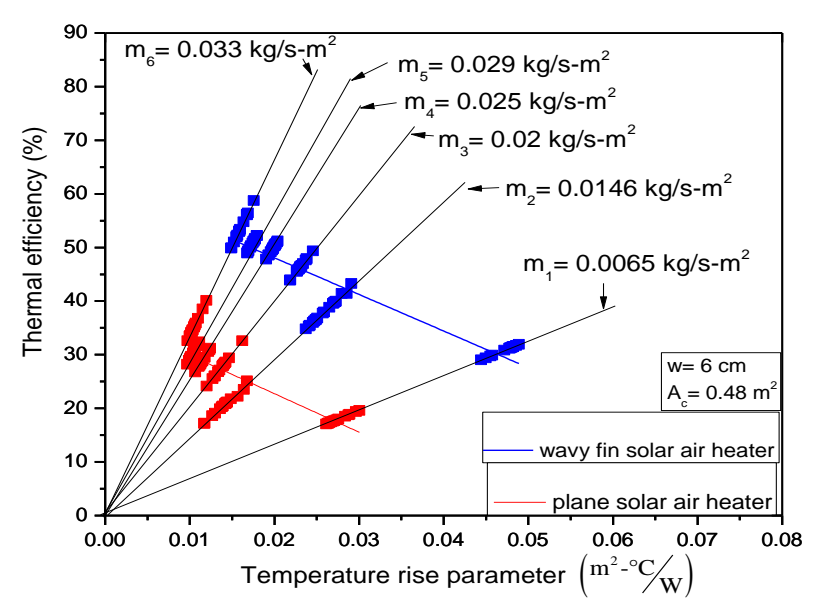

Figure 12. Performance plot for solar air heaters for fin spacing $6 \mathrm{~cm}$

Figs. 8-12 show the experimental values of thermal efficiencies as a function of air temperature rise parameter, i.e; $\left(\mathrm{T}_{\mathrm{o}}-\mathrm{T}_{\mathrm{i}}\right) / \mathrm{I}$ of plane and wavy finned absorber solar air heater for various fin spacings. Each line of these figures has been obtained from the linear regression fit of the data for the corresponding fin spacings of the wavy fin absorber solar air heater. Also, the plot for the plane solar air heater has been done for the comparison. The plot shows the increased thermal efficiency with the increase in mass velocity for the both plane as well as wavy fin absorber solar air heaters. It is seen from 
fig. 8 that the efficiency of plane solar air heater increases from $18.54 \%$ to $29.2 \%$ as the mass velocity increases from $0.0065 \mathrm{~kg} / \mathrm{s}-\mathrm{m}^{2}$ to $0.033 \mathrm{~kg} / \mathrm{s}-\mathrm{m}^{2}$. The corresponding values of thermal efficiency for wavy finned absorber has been obtained as $40 \%$ to $65 \%$. These values of efficiencies refer to the regression linear fit lines, whereas, the actual values have been found to vary for each mass velocity with the variation of $\left(\mathrm{T}_{\mathrm{O}^{-}}\right.$ $\left.\mathrm{T}_{\mathrm{i}}\right) / \mathrm{I}$ for a specific mass velocity. For the mass velocity of $0.0065-0.033 \mathrm{~kg} / \mathrm{s}-\mathrm{m}^{2}$ and fin spacing of $2 \mathrm{~cm}$, regression linear fit line show an enhancement in thermal efficiency of 2.15 - 2.23 times in thermal efficiency as compared to plane solar air heater. For the various fin spacing of wavy fin solar air heater and plane solar air heater, the value of thermal efficiencies and the respective enhancement in thermal efficiency obtained from the respective regression linear fit lines have been listed in Table 2. It shows that the fin spacing of $2 \mathrm{~cm}$ have the maximum enhancement in efficiency followed by fin spacing of $3,4,5$ and $6 \mathrm{~cm}$ respectively for all mass velocities.

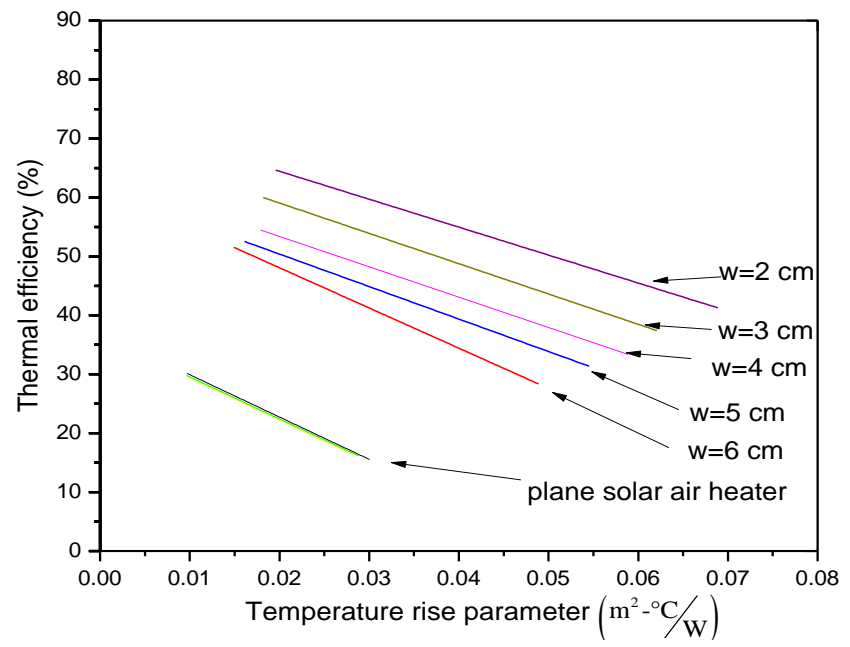

Figure 13. Performance plot for solar air heaters

Fig.13 shows the effect of fin spacing on the thermal performance of wavy fin absorber solar air heater as well as plane solar air heater. The performance lines plotted in the fig.13 are the linear regression fit lines of experimental data points of corresponding spacing and represented in figs. 8-12. Results show that the performance of wavy finned absorber is a strong function of fin spacing. The difference in the performance of these wavy finned solar air heaters is due to the enhanced heat transfer area and the effective heat transfer coefficient between the wavy fin absorber and air. It is clear from fig. 13 that the fin spacing $2 \mathrm{~cm}$ shows the overall best performance followed by fin spacing $3 \mathrm{~cm}, 4 \mathrm{~cm}, 5 \mathrm{~cm}$ and $6 \mathrm{~cm}$. This is due to the higher value of surface conductance $(\bar{h} \mathrm{~A})$ of the lower fin spacing absorb higher energy effectively and transfer more energy to the flowing air. The lower fin spacing, having high value of surface conductance, transfer energy from finned absorber to air more effectively and reduces the absorber plate temperatures and thus reduces the thermal losses from the absorber to the environment, results in enhanced thermal efficiency. The value of heat transfer coefficient $\bar{h}$ and ( $\bar{h} \mathrm{~A}$ ) overall heat conductance for the various fin spacing and mass velocities have been listed in Table 3. It can be seen from the table that the overall heat conductance and heat transfer coefficient increases with the decrease in fin spacing for both the minimum and maximum mass velocities. Thus the fin spacing of $2 \mathrm{~cm}$ is the most efficient absorber for all mass velocities. The enhancement in thermal efficiency of wavy finned absorber solar air heater as compared to plane solar air heater is found to decrease as the value of $\Delta \mathrm{T} / \mathrm{I}$ increases. The highest value of $\Delta \mathrm{T} / \mathrm{I}$ has been obtained for the lower fin spacing. This enhancement in thermal efficiency of these absorbers appears due to proceeding towards equality of average absorber plate temperature and air and also the decreasing values of absorber plate due to an appreciable rise in the value of overall conductance for the lower fin spacing $(2 \mathrm{~cm})$ absorber plate as compare to higher fin spacing $(3,4,5$ and $6 \mathrm{~cm})$. These conditions favours the increase in collector efficiency factor $\left(F^{\prime}\right)$ and hence enhanced collector heat removal factor related to outlet fluid temperature $\left(F_{o}\right)$. Also, the value of the overall loss coefficient, $\mathrm{U}_{\mathrm{L}}$ will decrease according to Shewan and Hollands[21] who have shown that the overall loss coefficient strongly depends on the mean absorber plate temperature as the collector efficiency factor approaches to unity.

The value of performance parameters $F_{o}(\tau \alpha)_{e}$ and $F_{o} U_{L}$ obtained from the intercept and slope of regression linear fit lines of various fin spacing are listed in Table 4. Also, the respective value of $F_{O}$ and $U_{L}$ has been calculated by calculating the constant value of $(\tau \alpha)_{e}$. The value of $(\tau \alpha)_{e}$ has been calculated as 0.854 , which is $1 \%$ greater than $(\tau \alpha)$ to include glass cover plate absorptance as suggested by Duffie and Beckman [2]. The solar air heaters test data presented as plots of thermal efficiency and $\left(T_{0}-T_{i}\right) / I$, the intercept and slope can be converted to $F_{R} U_{L}, F_{R}(\tau \alpha)_{e}$ and $F^{\prime} U_{L}$ by the equations (9-11).

Table 2. Experimental values of thermal efficiencies from regression best fit lines

\begin{tabular}{|c|c|c|c|c|c|}
\hline $\begin{array}{c}\text { Type of } \\
\text { Absorber }\end{array}$ & $\begin{array}{c}\text { Fin } \\
\text { Spacing } \\
\text { (cm) }\end{array}$ & $\begin{array}{c}\text { Mass flow } \\
\text { rate } \\
\left(\mathrm{kg} / \mathrm{s}-\mathbf{m}^{2}\right) \\
\end{array}$ & $\begin{array}{l}\text { Efficiency of plane } \\
\text { solar air heater }(\%)\end{array}$ & $\begin{array}{l}\text { Efficiency of wavy fin } \\
\text { solar air heater }(\%)\end{array}$ & $\begin{array}{c}\text { Enhancement in } \\
\text { efficiency } \\
(\%)\end{array}$ \\
\hline \multirow{2}{*}{ A1 } & \multirow{2}{*}{2} & 0.0065 & 18.2 & 40.1 & 120.33 \\
\hline & & 0.033 & 29.4 & 65.1 & 121.43 \\
\hline \multirow{2}{*}{ A2 } & \multirow{2}{*}{3} & 0.0065 & 18.6 & 38.4 & 106.45 \\
\hline & & 0.033 & 30 & 59.7 & 99 \\
\hline \multirow{2}{*}{ A3 } & \multirow{2}{*}{4} & 0.0065 & 18.4 & 35.6 & 93.48 \\
\hline & & 0.033 & 29.6 & 55.4 & 87.16 \\
\hline \multirow[b]{2}{*}{ A4 } & \multirow[b]{2}{*}{5} & 0.0065 & 17.6 & 31.6 & 79.54 \\
\hline & & 0.033 & 30 & 52.3 & 74.33 \\
\hline \multirow{2}{*}{ A5 } & \multirow[b]{2}{*}{6} & 0.0065 & 16.3 & 28.6 & 75.46 \\
\hline & & 0.033 & 30.1 & 50.4 & 67.44 \\
\hline
\end{tabular}


Table 3. Heat transfer coefficient and overall heat conductance

\begin{tabular}{|c|c|c|c|c|c|}
\hline $\begin{array}{c}\text { Type of } \\
\text { Absorber }\end{array}$ & $\begin{array}{c}\text { Fin Spacing } \\
(\mathbf{c m})\end{array}$ & $\begin{array}{l}\text { Mass velocities } \\
\quad\left(\mathrm{kg} / \mathrm{s}-\mathrm{m}^{2}\right)\end{array}$ & $\begin{array}{l}\text { Heat transfer } \\
\text { coefficient of plane } \\
\text { solar air heater } \\
\left(\mathrm{W} / \mathrm{m}^{2}-\mathrm{K}\right)\end{array}$ & $\begin{array}{c}\text { Heat transfer } \\
\text { coefficient of wavy } \\
\text { fin solar air heater } \\
\left(\mathrm{W} / \mathbf{m}^{2}-\mathrm{K}\right)\end{array}$ & $\begin{array}{c}\text { Overall Heat } \\
\text { conductance of } \\
\text { wavy fin solar air } \\
\text { heater }(\mathrm{W} / \mathrm{K})\end{array}$ \\
\hline A1 & 2 & $\begin{array}{c}0.0065 \\
0.033\end{array}$ & $\begin{array}{l}3.221 \\
7.914\end{array}$ & $\begin{array}{c}9.112 \\
29.801\end{array}$ & $\begin{array}{l}27.062 \\
88.508\end{array}$ \\
\hline $\mathrm{A} 2$ & 3 & $\begin{array}{c}0.0065 \\
0.033\end{array}$ & $\begin{array}{l}3.222 \\
7.894\end{array}$ & $\begin{array}{c}6.192 \\
20.345\end{array}$ & $\begin{array}{l}12.483 \\
41.015\end{array}$ \\
\hline A3 & 4 & $\begin{array}{c}0.0065 \\
0.033 \\
\end{array}$ & $\begin{array}{l}3.211 \\
7.914 \\
\end{array}$ & $\begin{array}{c}4.852 \\
15.782 \\
\end{array}$ & $\begin{array}{c}8.049 \\
26.182 \\
\end{array}$ \\
\hline A4 & 5 & $\begin{array}{c}0.0065 \\
0.033\end{array}$ & $\begin{array}{l}3.231 \\
7.849\end{array}$ & $\begin{array}{c}4.082 \\
13.301\end{array}$ & $\begin{array}{c}5.714 \\
18.621\end{array}$ \\
\hline A5 & 6 & $\begin{array}{c}0.0065 \\
0.033\end{array}$ & $\begin{array}{l}3.221 \\
7.927\end{array}$ & $\begin{array}{c}3.591 \\
11.741 \\
\end{array}$ & $\begin{array}{c}4.309 \\
14.089\end{array}$ \\
\hline
\end{tabular}

Table 4. Collector performance parameters

\begin{tabular}{|c|c|c|c|c|c|c|c|}
\hline $\begin{array}{c}\text { Fin Spacing } \\
(\mathbf{c m})\end{array}$ & $F_{0}(\tau \alpha)_{e}$ & $-F_{0} U_{L}$ & $F_{0}$ & $\begin{array}{c}\text { Fin } \\
\text { Spacing } \\
(\mathbf{c m})\end{array}$ & $F_{0}(\tau \alpha)_{e}$ & $-F_{0} U_{L}$ & $F_{0}$ \\
\hline 2 & 0.7391 & 4.74 & 0.865 & 5 & 0.6140 & 5.51 & 0.719 \\
\hline 3 & 0.6933 & 5.14 & 0.812 & 6 & 0.5971 & 6.82 & 0.692 \\
\hline 4 & 0.6479 & 5.48 & 0.759 & & & & \\
\hline
\end{tabular}

Table 5. Collector performances as a function of mass velocities

\begin{tabular}{|c|c|c|c|c|c|c|c|c|c|}
\hline \multirow{2}{*}{$\begin{array}{c}\text { Fin } \\
\text { Spacing } \\
(\mathbf{c m})\end{array}$} & \multicolumn{9}{|c|}{ Mass velocities $\left(\mathrm{kg} / \mathrm{s}-\mathrm{m}^{2}\right)$} \\
\cline { 2 - 11 } & $F_{R}(\tau \alpha)_{e}$ & $F_{R} U_{L}$ & $F^{\prime} U_{L}$ & $F_{R}(\tau \alpha)_{e}$ & $F_{R} U_{L}$ & $F^{\prime} U_{L}$ & $F_{R}(\tau \alpha)_{e}$ & $F_{R} U_{L}$ & $F^{\prime} U_{L}$ \\
\hline & 0.7339 & 4.707 & 5.69 & 0.7374 & 4.730 & 5.36 & 0.7381 & 4.734 & 5.11 \\
\hline 2 & 0.6880 & 5.105 & 6.30 & 0.6916 & 5.132 & 5.89 & 0.6922 & 5.137 & 5.58 \\
\hline 3 & 0.6425 & 5.439 & 6.82 & 0.6461 & 5.470 & 6.35 & 0.6468 & 5.475 & 5.98 \\
\hline 4 & 0.6089 & 5.465 & 6.86 & 0.6124 & 5.496 & 6.38 & 0.6130 & 5.502 & 6.02 \\
\hline 5 & 0.6108 & 6.281 & 8.24 & 0.6151 & 6.322 & 8.24 & 0.6158 & 6.329 & 7.03 \\
\hline 6 & 0.3452 & 6.755 & 8.64 & 0.3475 & 6.802 & 7.54 & 0.3479 & 6.810 & 7.63 \\
\hline Plane & & & & & & & \multicolumn{3}{c|}{0.033} \\
\hline
\end{tabular}

The value of these parameters for the various fin spacing as a function of mass velocity are listed in Table 5 . The values of $F_{R}, U_{L}$ and $F^{\prime}$ can be calculated by using a constant value of $(\tau \alpha)_{e}=0.854$ for the various mass velocities

Fig. 14 shows the thermal efficiency comparison of $6 \mathrm{~cm}$ fin spacing with some solar air heater efficiencies available in the literature. The thermal efficiency of wavy fin solar air heater is greater than offset finned solar air heater of Youcef -Ali and Desmons [22] by $10.36 \%$ and finned solar air heater of Karim and Hawlader[23] by $29.63 \%$ for the investigated range of system and operating parameters. Also, the thermal efficiency values of Karim and Hawlader[15] for plane solar air heater show a deviation $\pm 3.48 \%$ from the plane solar air heater of present result. This holds a good agreement between the experimental values and makes the perfection of data collected through experimentation.

Table 6. Accuracy of measuring instruments

\begin{tabular}{|c|c|c|}
\hline Sl. No. & Name of Instrument & Accuracy \\
\hline 1 & Pyranometer & $\pm 0.5^{\circ} \%$ \\
\hline 2 & Digital Manometer & $\pm 0.3 \%$ \\
\hline 3 & Thermocouple & $\pm 0.1^{\circ} \mathrm{C}$ \\
\hline
\end{tabular}

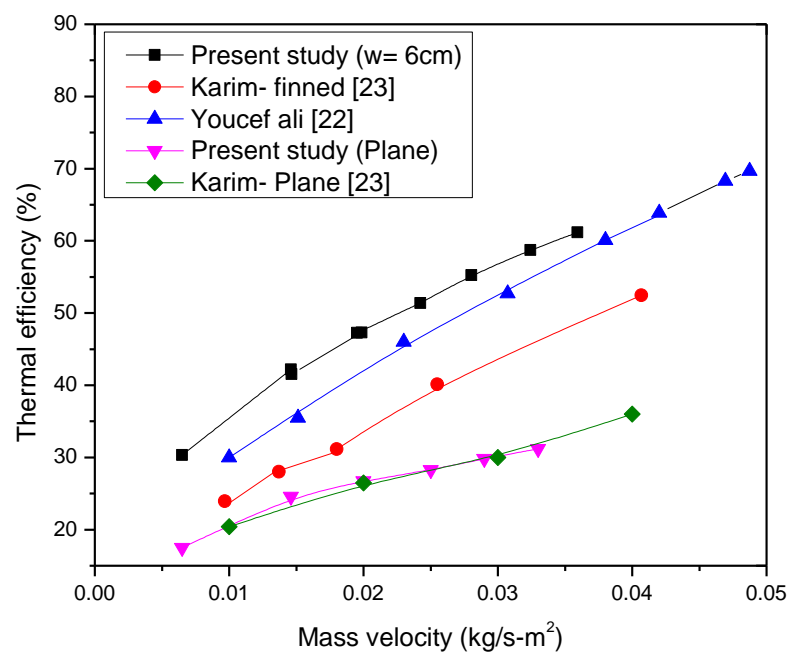

Figure 14. Thermal efficiency comparison of $6 \mathrm{~cm}$ fin spacing solar air heater with some solar air heaters available in literature 


\section{CONCLUSIONS}

1. The thermal performance of a solar air heater can be enhanced by using wavy finned absorber and the fin spacing and mass velocity is important parameters for the performance.

2. The effect of insolation, fin spacing and mass velocities on thermal performance has been examined experimentally.

3. The highest value of rise in air temperature has been found for the lowest mass velocity of $0.0065 \mathrm{~kg} / \mathrm{s}-$ $\mathrm{m}^{2}$ as $64.33,55.31,52.23,50.83$ and $48.13^{\circ} \mathrm{C}$ for the fin spacing 2, 3, 4, 5 and $6 \mathrm{~cm}$ respectively between 12:00 hr to 13:00 hr of local time as the insolation was maximum, i.e., 1069, 1027, 940, 933 and 956 $\mathrm{W} / \mathrm{m}^{2}$ respectively.

4. Improved thermal performance of wavy fin solar air heater has been found due to the improved surface conductance of the finned absorber plate.

5. The maximum enhancement in thermal efficiency for wavy finned absorber solar air heater for fin spacing of $2 \mathrm{~cm}$ has been found to be $28.71 \%$ as compared to fin spacing of $6 \mathrm{~cm}$ and $116.67 \%$ as compared to plane solar air heater.

6. The maximum value of $\Delta \mathrm{T} / \mathrm{I}$ for wavy fin spacing 2 $\mathrm{cm}, 6 \mathrm{~cm}$ and plane solar air heater has been achieved as $0.067,0.048$ and $0.029 \mathrm{~m}^{2}{ }^{\circ} \mathrm{C} / \mathrm{W}$ respectively.

7. Wavy finned absorber solar air heater is found to be 67.44 to 121.43 percent thermally efficient as compared to plane solar air heater within the investigated range of system i.e. fin spacing of 2 to $6 \mathrm{~cm}$ and operating parameters i.e. mass velocity of $0.0065-0.033 \mathrm{~kg} / \mathrm{s}-\mathrm{m}^{2}$

\section{REFERENCES}

[1] Sukhatme SP, Nayak JK. (1996). Principles of thermal collection and storage, 2nd Edition. Tata Mc Graw Hill Education, New Delhi, India.

[2] Duffie JA, Beckman WA. (1980). Solar Engineering of Thermal Processes, New York: Wiley.

[3] Garg HP, Datta G, Bhargava AK. (1989). Performance studies on a finned air heater. Energy 14(2): 87-92. https://doi.org/10.1016/0360-5442(89)90082-0

[4] Reddy TA, Gupta CL. (1980). Generating application design data for sola air heating systems. Solar Energy 25: $\quad 527-530 . \quad$ https://doi.org/10.1016/0038092X(80)90085-7

[5] Yeh HM, Ho CD, Hou JZ. (2002). Collector efficiency of double-flow solar air heaters with fins attached. Energy 27: 715-727. https://doi.org/10.1016/S03605442(02)00010-5

[6] Bhushan B, Singh R. (2011). Nusselt number and friction factor correlations for solar air heater duct having artificial roughened absorber plate. Solar Energy 85:

1109-1118. https://doi.org/10.1016/j.solener.2011.03.007

[7] Pandey NK, Varun BVK. (2016). Experimental investigation of heat transfer augmentation using multiple arcs with gap on absorber plate of solar air heater. Solar Energy 134: 314-326. https://doi.org/10.1016/j.solener.2016.05.007
[8] Golneshan AA, Nemati H. (2014). Exergy analysis of Unglazed Transpired Solar Collectors (UTCs). Solar Energy 107: 272-277. https://doi.org/10.1016/j.solener.2014.04.025

[9] Ramadan MRI, Sebaii AAEl, Aboul-Enein S, El-Bialy E. (2007). Thermal performance of a packed bed double-pass solar air heater. Energy 32: 1524-1535. https://doi.org/10.1016/j.energy.2006.09.019

[10] Sharma SP, Saini JS, Varma HK. (1991). Thermal performance of packed bed solar air heaters. Solar Energy 47(2): 59-67. https://doi.org/10.1016/0038092X(91)90035-U

[11] Li MJ, Zhang H, Zhand J, Mu YT, Tian E, Dan D, Zhang XD, Tao WQ. (2018). Experimental and numerical study and comparison of performance for wavy fin and a plain fin with radiantly arranged winglet around each tube in fin-and-tube heat exchangers. Applied Thermal Engineering. 133: 298-307. https://doi.org/10.1016/j.applthermaleng.2018.01.012

[12] Gun W, Gwang K, Hoon R. (2018). Optimization of study of cross-cut flow control for heat transfer enhancement in wavy fin heat exchangers: Concept of cross-cut reference length. Applied Thermal Engineering 134: 527-536. https://doi.org/10.1016/j.applthermaleng.2018.02.021

[13] Zhand XL, Wang YC, Li M, Wang SD, Li XL. (2017). Improved flow and heat transfer characteristics for heat exchanger by using a new humped wavy fin. Applied Thermal Engineering 124: 510-520. https://doi.org/10.1016/j.applthermaleng.2017.06.068

[14] Ranganayakulu C, Luo X, Kabelac S. (2016). The single- blow transient testing technique for offset and wavy fins of compact plate-fin heat exchangers. Applied Thermal Engineering 111: 1588-1595. https://doi.org/10.1016/j.applthermaleng.2016.05.118

[15] Kumar R, Chand P. (2017). Performance enhancement of solar air heater using herringbone corrugated fins. Energy 127: 271-279. https://doi.org/10.1016/j.energy.2017.03.128

[16] Priyam A, Chand P. (2016). Thermal and thermohydraulic performanceof wavy finned absorber solar air heater. Solar Energy 130: 250-259. https://doi.org/10.1016/j.solener.2016.02.030

[17] Priyam A, Chand P. (2016). Effect of collector aspect ratio on the thermal performance of wavy finned absorber solar air heater. Energy and Power Engineering 562-566.

[18] Priyam A, Chand P. (2018). Effect of wavelength and amplitude on the performance of wavy finned absorber solar air heater. Renewable Energy 119: 690-702. https://doi.org/10.1016/j.renene.2017.12.010

[19] Ashrae standard 93-77 (ANSI B 1981-1977). (1977). Methods of testing to determine the thermal performance of solar collectors. ASHRAE, New York.

[20] Kline SJ, McClintock FA. (1953). Describing uncertainties in single sample experiments. Mechanical Engineering 75: 3-8.

[21] Shewen EC, Hollands KGT. (1979). Equations for presenting the $\mathrm{U}_{\mathrm{t}^{-}}$dependence in collector test procedures. Proceedings of Int. Solar Energy Society. Atlanta, GA. 360-364.

[22] Youcef-Ali S, Desmons DY. (2006). Numerical and experimental study of a solar equipped with offset rectangular plate fin absorber plate. Renewable Energy 
31:

2063-2075.

https://doi.org/10.1016/j.renene.2005.10.008

[23] Karim MA, Hawlader MNA. (2006). Performance investigation of flat, $\mathrm{V}$ - corrugated and finned air collectors. $\quad$ Energy 31 : 452-470. https://doi.org/10.1016/j.energy.2005.03.007

\section{NOMENCLATURE}

$\bar{h}$

$\mathrm{A}_{\mathrm{c}}$ amp $\mathrm{F}^{\prime}$ $F_{R}$

$\mathrm{H}$

I

L

$\mathrm{L}_{\text {act }}$ $\bar{h}$

$\mathrm{A}_{\mathrm{c}}$ amp

$F^{\prime}$

$\mathrm{F}_{\mathrm{R}}$

$\mathrm{L}_{\mathrm{f}}$

$\mathrm{N}_{\mathrm{gc}}$

$\mathrm{T}_{\mathrm{i}}$

W

W

$\delta_{\mathrm{f}}$

To

A

Cp

kgw

Tfm

Tpm

$\dot{m} / A_{c}$

$\Delta \mathrm{T}$

$\lambda$

$\mathrm{Cd}$

$\bar{h} A$

$(\tau \alpha)$

Sins

$\eta$ heat transfer coefficient $\left(\mathrm{W} / \mathrm{m}^{2} \mathrm{~K}\right)$

collector area $\left(\mathrm{m}^{2}\right)$

amplitude of wavy fin

collector efficiency factor collector heat removal factor

duct height $(\mathrm{cm})$

insolation $\left(\mathrm{W} / \mathrm{m}^{2}\right)$

length of collector $(\mathrm{m})$

actual length of fin (m)

heat transfer coefficient $\left(\mathrm{W} / \mathrm{m}^{2} \mathrm{~K}\right)$

collector area $\left(\mathrm{m}^{2}\right)$

amplitude of wavy fin

collector efficiency factor

collector heat removal factor

height of fin $(\mathrm{cm})$

number of glass covers

inlet air temperature $(\mathrm{K})$

fin spacing $(\mathrm{cm})$

width of collector $(\mathrm{m})$

thickness of fin $(\mathrm{mm})$

outlet air temperature(K)

total heat transfer area $\left(\mathrm{m}^{2}\right)$

specific heat of $\operatorname{air}(\mathrm{J} / \mathrm{kgK})$

thermal conductivity of glass wool

(W/m-K)

mean temperature of air(K)

mean temperature of absorber plate $(\mathrm{K})$

mass velocity $\left(\mathrm{kg} / \mathrm{s}-\mathrm{m}^{2}\right)$

rise in temperature $(\mathrm{K})$

wavelength of wavy fin ( $\mathrm{mm}$ )

coefficient of discharge

thermal conductance $(\mathrm{W} / \mathrm{K})$

transmittance absorptance product

thickness of insulation ( $\mathrm{mm}$ )

thermal efficiency

\section{APPENDIX}

\section{Error analysis}

Although extreme care has been taken to perform experiment but there is always a chance of error in experimental measurements. So, it is necessary to determine maximum possible error in the experimental measurements. The error analysis was done for the error interval associated with experimental results. The methodology suggested by cline and Mc clintock [20] has been used to measure the error. If the value of any parameter is calculated using certain measured quantities then error in measurement of ' $\varphi$, (parameters) is given as:

$$
\frac{\delta \varphi}{\varphi}=\left[\left(\frac{\delta \varphi}{\partial x_{1}} \delta x_{1}\right)^{2}+\left(\frac{\delta \varphi}{\partial x_{2}} \delta x_{2}\right)^{2}+\ldots \ldots \ldots \ldots . . .+\left(\frac{\delta \varphi}{\partial x_{n}} \delta x^{n}\right)^{2}\right]^{0.5}
$$

where $\delta x_{1}, \delta x_{2}, \delta x_{3} \ldots . . \delta x_{n}$ are the possible errors in measurements $x_{1}, x_{2}, x_{3} \ldots x_{n}$ and $\delta \varphi$ is called as absolute uncertainty and $\delta \varphi / \varphi$ is known as relative uncertainty.

1. Area of absorber plate

$$
\begin{aligned}
A_{p}= & (W \times L) \\
\delta A p= & {\left[\left(\frac{\delta A_{p}}{\delta L} \times \delta L\right)^{2}+\left(\frac{\delta A_{p}}{\delta W} \times \delta W\right)^{2}\right] } \\
\delta A_{p}= & {[W \times \delta l]^{2}+[L \times \delta W]^{2} } \\
\delta A_{p}= & {\left[\left(\frac{W x \delta L}{W x L}\right)^{2}+\left(\frac{L x \delta W}{W x L}\right)^{2}\right]^{0.5} } \\
\delta A_{p}= & {\left[\left(\frac{1}{1200}\right)^{2}+\left(\frac{1}{400}\right)^{2}\right]^{0.5} } \\
= & 2.63 \times 10^{-3}=0.263 \%
\end{aligned}
$$

2. Area of flow

$$
\begin{aligned}
& A_{f}=\left(W \times L_{a c t}\right)+n\left(L_{f} \times L_{a c t}\right) \\
& \delta A_{f}=\left[\left(\frac{\delta A}{\delta L} \times \delta L\right)^{2}+\left(\frac{\delta A}{\delta W} \times \delta W\right)^{2}+n\left(\frac{\delta\left(L_{f} L_{a c t}\right)}{\delta L_{a c t}}\right)^{2}+\left(\frac{\delta\left(L_{f} L_{a c t}\right)}{\delta L_{a c t}} \times L_{f}\right)^{2}\right] \\
& \delta A_{f}=[W \times \delta l]^{2}+\left[L_{a c t} \times \delta W\right]^{2}+\eta\left(L_{f} \times \delta L_{a c t}\right)^{2}+\left(L_{f} L_{a c t}\right)^{2} \\
& \delta A_{f}=\left(\frac{\delta L_{a c t}}{L_{a c t}}\right)^{2}+\left(\frac{\delta W}{W}\right)^{2}+7\left[\left(\frac{\delta L_{a c t}}{L_{a c t}}\right)^{2}+\left(\frac{\delta L_{f}}{\delta L_{f}}\right)^{2}\right]^{0.5} \\
& \delta A_{f}=\left[\left(\frac{1}{1390}\right)^{2}+\left(\frac{1}{400}\right)^{2}+7\left[\left(\frac{1}{45}\right)^{2}+\left(\frac{1}{1390}\right)^{2}\right]\right]^{0.5} \\
& \delta A_{f}=0.05888 \\
& \delta A_{f}=5.888 \%
\end{aligned}
$$

3. Area of orifice meter $\left(A_{o}\right)$

$$
\begin{aligned}
& A_{0}=\frac{\pi}{4} d_{2}^{2} \\
& \frac{\delta A_{o}}{\delta d_{2}}=\frac{2 \pi d_{2}}{4}=\frac{\pi d_{2}}{2} \\
& \delta A_{o}=\left(\frac{\pi d_{2}}{2}\right) \delta d_{2} \\
& \frac{\delta A_{o}}{A_{o}}=\frac{\pi d_{2} \delta d_{2} \times 4}{2 \times \pi \times d_{2}^{2}}=\frac{2 \delta d_{2}}{d_{2}}=\frac{2 \times(0.05)}{19}=0.526 \%
\end{aligned}
$$


4. Mass flow rate $(\dot{m})$

$\dot{m}=C_{d} A_{0}\left[\frac{2 \rho \Delta P}{1-\beta^{4}}\right]^{0.5}$

$\frac{\delta \dot{m}}{\dot{m}}=\left[\left(\frac{\delta C_{d}}{C_{d}}\right)^{2}+\left(\frac{\delta A_{0}}{A_{0}}\right)^{2}+\frac{1}{4}\left(\frac{\delta \rho}{\rho}\right)^{2}+\frac{1}{4}\left(\frac{\delta(\Delta P)}{(\Delta P)}\right)^{2}+\frac{1}{4}\left(\frac{\delta \beta}{\beta}\right)^{2}\right]^{0.5}$

$=\left[(0.016)^{2}+(0.00526)^{2}+\frac{1}{4}(0.0083)^{2}+\frac{1}{4}\left(\frac{1}{25}\right)^{2}+\frac{1}{4}(0.00121)^{2}\right]^{0.5}$ $=0.0437$ or $4.37 \%$

5. Useful heat gain $\left(Q_{u}\right)$

$Q_{u}=\dot{m} C_{p}\left(T_{o}-T_{i}\right)$

$$
\begin{aligned}
\frac{\delta Q_{u}}{Q_{u}} & =\left[\left(\frac{\delta \dot{m}}{\dot{m}}\right)^{2}+\left(\frac{\delta C p}{C p}\right)^{2}+\left(\frac{\delta(\Delta T)}{(\Delta T)}\right)^{2}\right]^{0.5} \\
& =\left[(0.0437)^{2}+(1 / 1005)^{2}+(0.5 / 15.2)^{2}\right]^{0.5} \\
& =0.0547 \text { or } 5.47 \%
\end{aligned}
$$

6. Heat transfer coefficient $(\bar{h})$

$$
\begin{aligned}
\bar{h} & =\frac{Q_{u}}{A_{p}\left(T_{p m}-T_{f m}\right)} \\
\frac{\delta \bar{h}}{\bar{h}} & =\left[\left(\frac{\delta Q_{u}}{Q_{u}}\right)^{2}+\left(\frac{\delta A_{p}}{A_{p}}\right)^{2}+\left(\frac{\delta T_{p f}}{T_{p f}}\right)^{2}\right]^{0.5} \\
& =\left[(0.0547)^{2}+(0.00358)^{2}+\left(\frac{1}{12}\right)^{2}\right]^{0.5} \\
& =0.09974 \text { or } 9.974 \%
\end{aligned}
$$

